EWELINA GRYGIER

INSTYTUT SZTUKI, POLSKA AKADEMIA NAUK

\title{
ROZWÓJ FONOGRAFII I PROCESY GLOBALIZACYJNE A REPERTUAR I WYDAWNICTWA PŁYTOWE MUZYKÓW ULICY*
}

\author{
WSTĘP
}

Dejestrowanie i odtwarzanie dźwięku stało się możliwe już pod koniec XIX w.

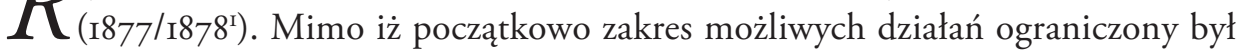
niedoskonałościami nowo powstałego urządzenia - fonografu ${ }^{2}$, wynalazek Thomasa Alvy Edisona znacząco wpłynął na historię muzyki, oddziałując zarówno na wykonawstwo, percepcję, wynagrodzenie artysty ${ }^{4}$, jak również dokumentowanie i analizowanie zjawisk muzycznych's, a wraz z postępującym rozwojem technologii zapisu dźwięku rosły nie tylko możliwości dokumentacyjne życia (muzycznego), lecz także rodził się przemysł muzyczny, którego wytwory towarzyszą nam dziś niemalże na każdym kroku. Z ich pomocą często wpływa się na nasze nastroje, pracę i decyzje

* Artykuł został przygotowany na podstawie ukończonych fragmentów powstającej w Instytucie Sztuki PAN dysertacji doktorskiej Artysta, performer, żebrak. Zjawisko muzykowania ulicznego w Polsce w XXI wieku $w$ świetle teorii performansu.

I Pierwsza publiczna prezentacja fonografu miała miejsce na początku grudnia I877 r. w Nowym Jorku, pod koniec tego miesiąca Edison złożył wniosek patentowy, a w I878 r. uzyskał patent na wynalezione przez siebie urządzenie do zapisu i odtwarzania dźwięku, zob.: Katarzyna Janczewska-Sołomko, Zachować dźwięk. Katalog wystawy w Bibliotece Narodowej, Warszawa 2000, s. 9-Io.

2 Początkowo fonograf znacznie lepiej sprawdzał się podczas zapisywania na wałku instrumentów dętych niż instrumentów strunowych, a im wyższa była częstotliwość dźwięku, tym bardziej wyraźny otrzymywano zapis. Solowe nagrania były technicznie bardziej doskonałe, niż rejestracje rozbudowanych zespołów instrumentalnych o obsadzie większej niż dziesięć osób. Ponadto, z uwagi na swoją niewielką pojemność (dwie do czterech minut w zależności od rodzaju wałka woskowego), fonograf nie pozwalał na dokumentowanie dłuższych utworów, zob.: K. Janczewska-Sołomko, Zachować dźwięk, s. I3-I4.

3 Ewa Kofin, Muzyka wokót nas. Studium przeobrażeń recepcji muzyki w dobie elektronicznych środków jej przekazywania, Wrocław 20I2, s. I2-I3.

4 K. Janczewska-Sołomko, Zachować dźwięk, s. 3I.

5 Jacek Jackowski, Zachować dawne nagrania. Zarys historii dokumentacji fonograficznej i filmowej polskich tradycji muzycznych i tanecznych, cz. I (przetom XIX i XX w. - do drugiej wojny światowej), Warszawa 20I4, s. 7, II, I35 i in. 
konsumenckie $\left(\operatorname{muzak}^{6}\right)$, popularyzuje, a nawet kreuje nowe gwiazdy muzyczne, rozpowszechniając przy tym określony repertuar. Rozwój fonografii i jej kulturotwórczy potencjał ${ }^{7}$, wraz z drugim istotnym czynnikiem - globalizacją oraz skorelowanym z nią zjawiskiem glokalizacji, wpłynął także na działalność muzyków ulicy.

Charakterystyczna dla współczesnego świata szybka, globalna wymiana treści (w tym także tych związanych z muzyka) pomiędzy centrum i peryferiami związana jest silnie z powszechnym dostępem do mediów, w tym w szczególności do Internetu:

[...] młodzież z różnych krajów zna ten sam repertuar światowych hitów (czego dowodem są listy przebojów międzynarodowych). Owa wspólnota natury muzycznej to nawet jeden z głównych środków identyfikacyjnych, porozumiewawczych i więzi grupowej młodzieży (poza samym wiekiem), wzmagany jeszcze komunikacyjnym pośrednictwem internetu 8 .

Dzięki współczesnym mediom w łatwy sposób można dotrzeć do tego, co dzieje się na krańcach globalnej wioski, jak również upowszechnić to, co lokalne. Tym samym także niezależni artyści (w tym muzycy ulicy) zyskują platformę do prezentowania swojej muzyki, równocześnie pozostając na bieżąco ze współczesną kulturą muzyczną. Globalizacja i glokalizacja są bowiem zjawiskami współzależnymi, oddziaływającymi na siebie, a „[...] siły przenikające z rozmaitych metropolii do nowych społeczeństw ulegają w nich w ten czy inny sposób równie szybkiej indygenizacji, gdy się w nich instalują - dotyczy to zarówno muzyki i stylów zamieszkiwania, jak nauki i terroryzmu, przedstawień i konstytucji”" Indygenizacja oznacza bowiem dostosowanie tego, co globalne do lokalnych warunków, z kolei glokalizacja to zjawisko odwrotne, adaptacja „[...] kultur lokalnych do globalnych uwarunkowań życia, jak również wnoszenie lokalnych treści i wartości do globalnego obiegu” ${ }^{\text {”o }}$.

Procesy globalizacyjne oraz szybki rozwój komunikacji i technologii rzutują nie tylko na przepływ idei ( $w$ tym repertuaru), lecz także na możliwość szybkiego i ciągłego podróżowania. Migracje ludzi silnie wpływają na przemieszczanie się repertuaru, przykładowo w Sztokholmie większość muzyków ulicy stanowią obcokrajowcy, w tym głównie wykonawcy rosyjskojęzyczni, wraz z którymi przywędro-

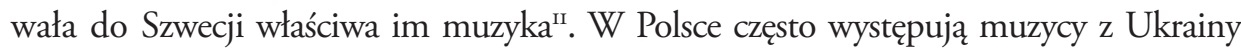

6 E. Kofin, Muzyka wokót nas, s. 75.

7 Mieczysław Kominek, Zaczęto się od fonografu, Kraków 1986, s. 235.

8 E. Kofin, Muzyka wokót nas, s. 49.

9 Arjun Appadurai, Nowoczesność bez granic. Kulturowe wymiary globalizacji, przekł. Zbigniew Pucek, Kraków 2005, s. 49-50.

IO Barbara Pasamonik, „Globalizacja kultury czy glokalizacja kultur?”, w: Krótkie wyktady z socjologii: kategorie, problemy, subdyscypliny, red. Anna Firkowska-Mankiewicz, Tatiana Kanasz, Elżbieta Tarkowska, Warszawa 20I3, s. I34.

II Rebecka Björk, Bakom kulisserna i Stockholms gatmusikliv, Stockholms Universitet 2003 (dysertacja doktorska), s. I4. 
i Białorusi, a w stolicy Austrii chętnie muzykują Polacy, Słowacy i Bułgarzy ${ }^{12}$. Jednak nawet pomimo otwartych granic i łatwości podróży, istnieją inne czynniki kształtujące oblicze muzyki ulicy w poszczególnych krajach. Instrumentalistę grającego na dudach szkockich spotkać można zarówno w Edynburgu, jak i we Wrocławiu, przy czym niekoniecznie zawsze musi on być Szkotem z pochodzenia. Jednak, ze względu na lokalne przepisy dotyczące muzykowania, w wielu niemieckich miastach, np. w Monachium, dudziarze nigdy nie dadzą koncertu ulicznego, podobnie jak popularne w Polsce rumuńskie i mołdawskie orkiestry dęte - używanie tych instrumentów w przestrzeni publicznej jest tam bowiem po prostu zabronione. Tym samym funkcjonujące w konkretnych miejscach (miastach) lokalne regulacje prawne aktywnie wpływają na kształt muzyki ulicy. Pośrednio rzutują one także na wykonywany w przestrzeni publicznej repertuar, który bywa ściśle związany z wykorzystywanym instrumentarium ${ }^{\mathrm{I} 3}$.

Wybór repertuaru jest czynnością, na którą oddziałują zarówno czynniki wewnętrzne, jak i zewnętrzne. Najistotniejszymi determinantami wydają się upodobania i umiejętności danego muzyka, jednakże istnieje także gros motywacji zewnętrznych, które wpływają na ostateczny kształt tego, co jest wykonywane w przestrzeni publicznej. Wśród impulsów zewnętrznych wymienić należy ograniczenia instrumentu oraz chęć przypodobania się gustom publiczności, niekiedy także regulacje dotyczące muzykowania ulicznego.

\section{REPERTUAR HISTORYCZNYCH WYKONAWCÓW PREZENTUJĄCYCH SIĘ} W PRZESTRZENI PUBLICZNEJ

W XVIII w. Giovanii Barberi skonstruował katarynkę, która w kolejnym stuleciu znacznie zmieniła myślenie o krajobrazie dźwiękowym miasta, stając się stałą bywalczynią ulic Londynu, Berlina czy Warszawy. Gdyby Michael Bass, londyńczyk, który postanowił z pomocą prawa walczyć z muzykami ulicy, mógł znać schaferowskie rozróżnienie na pejzaż dźwiękowy typu lo-fi i hi-fi, z pewnością powiedziałby, że audiosfera dziewiętnastowiecznego Londynu należy do tej drugiej kategorii ${ }^{\mathrm{I}}$. W Polsce podobnego zdania co Bass był varsavianista Wiktor Gomulicki, który pisał wręcz o „dręczycielach uszów” (sic!) - tę barwnie nazwaną kategorię tworzyły trzy typy muzyków: „oprawcy koncertowi”, „muzykalne sąsiedztwa” oraz „muza żebrząca” czy-

I2 Ewelina Grygier, „Street Music. A Case Study of Three European Cities: Vienna, Warsaw and Wrocław”, w: Post-ip’z - Revista do Fórum Internacional de Estudos em Música e Dança, red. Ana Flávia Miguel, Aoife Hiney, Clarissa Foletto, Gilvano Dalagna, Marcos Vinicius, Araújo, Rui Oliveira, Aveiro 2013, s. 73.

I3 Zob. np.: Informationen zur Straßenmusik in Stuttgart (pkt. 6, s. I) czy Straßenmusik in Erlangen (pkt. 9), online: https://www.stuttgart.de/medien/ibs/WEB_Strassenmusikanten.pdf, dostęp I8 VIII 2020, https://www.erlangen.de/desktopdefault.aspx/tabid-I443/IO7_read-33642/, dostęp I8 VIII 2020.

I4 Por:: Michael Thomas Bass, Street Music in the Metropolis. Correspondence and Observations on the Existing Law, and Proposed Amendments, London 1864. 


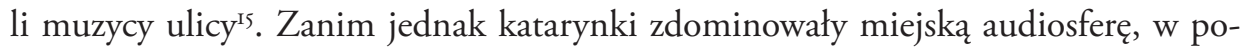
przednich stuleciach była ona zagospodarowywana przez innych aktorów przestrzeni publicznej posługujących się dźwiękiem. Wśród nich wyróżnić możemy między innymi muzyków miejskich (trębaczy, piszczków), kupców (okrzyki sprzedawców i domokrążców ${ }^{16}$ ), dziadów wędrownych (lirników), stróżów nocnych, żaków, a także tych wszystkich, którzy, pracując z dźwiękiem, pełnili jednocześnie inne funkcje społeczne, byli zębołomami, akrobatami czy pucybutami ${ }^{17}$. Z czasem ważnym elementem miasta stał się także muzyczny folklor miejski i wykonujące go kapele podwórkowe. Repertuar wymienionych wyżej grup był zróżnicowany, od krótkich instrumentalnych sygnałów (stróże, muzycy miejscy), do długich utworów wokalnych bądź wokalno-instrumentalnych wykonywanych przez wędrownych dziadów.

Dobrze zbadane i udokumentowane są utwory wykonywane niegdyś przez dziadów wędrownych, którzy łączyli świat realny z nadprzyrodzonym (dziad jako symboliczne uosobienie przodków, wędrowca, a nawet samego Boga), oraz miejski z wiejskim (dziad lirnik występował zarówno pod kościołami, na jarmarkach, jak i zachodził do wsi) ${ }^{18}$.

Wiadomości na temat repertuaru artystów występujących dawniej w przestrzeni publicznej pochodzą z różnych źródeł, zarówno z dokumentów historycznych, dokumentów życia społecznego, literatury specjalistycznej, jak i z prasy. Nie tylko źródła, lecz także szczegółowość podawanych informacji jest różna. $\mathrm{Z}$ dwudziestowiecznych artykułów można było dowiedzieć się, że nieraz „[...] zjawia się na podwórzu solo lub duet wokalny, parodiujący nabożne lub światowe pienia [...]”'গ9. Jakie to konkretnie były utwory? O tym autor tekstu milczy. Także niespełna trzydzieści lat później niewymienione zostały żadne tytuły: „[...] zaroiło się na podwórku [...]. Katarynka piszczy, gwiżdże, porykuje najnowsze szlagiery sprzed dwu laty, bęben na plecach grzmi niczym furman na Karolewskiej Szosie [...]”20. W rzadszych przypadkach nasza wiedza o dawnym repertuarze obejmuje konkretne tytuły wykonywanych utworów:

I5 Wiktor Gomulicki, Przy stońcu i przy gazie: szkice z miasta, Warszawa I888, s. I72.

I6 Najistotniejszym dziełem w tym zakresie wydaje się zbiór rycin Matthaeusa Diescha przedstawiający gdańskich wywoływaczy. Zbiór ten został już szczegółowo omówiony, por. Barbara Brzezińska, „Zawołania gdańskich domokrążców (1762-1765)”, Muzyka 50 (2013) nr 2, s. 45-77.

I7 Por.: Peter Burke, Kultura ludowa we wczesnonowożtnej Europie, przekł. Robert Pucek, Michał Szczubiałka, Warszawa 2009, s. II3-II4.

I8 Na repertuar dziadowski składały się między innymi: legendy hagiograficzne i pieśni o świętych, legendy maryjne, legendy apokryficzne, pieśni o śmierci, pieśni o końcu świata i Sądzie Ostatecznym, pieśni o upadku obyczajów, pieśni nowiniarskie czy utwory traktujące o sierotach i dzieciobójczyniach. Twórczość ta spełniała rozliczne funkcje: estetyczne, rozrywkowe, regulacyjne, moralnie-oceniające, patriotyczno-wychowawcze i etnointegrujące, prorocze, uzdrowicielskie czy informacyjne, zob.: Piotr Grochowski, Dziady. Rzecz o wędrownych żebrakach i ich pieśniach, Toruń 2009, s. 214-223; Katia Michajłowa, Dziad wędrowny w kulturze ludowej Stowian, przekł. Hanna Karpińska, Warszawa 2010, s. 209-240.

19 „Ze świata Tonów”, Dziennik Eódzki: Pismo Przemystowe, Handlowe i Literackie 8 (I89I) nr 215, s. I.

20 Faun, „NNa podwyrzu»...Monografia łódzkiego podwórka. (Szkic z natury)”, Eódzkie Echo Wieczorne I (I925) nr 224, s. 6. 
„[...] umiałem dopiero trzy kawałki: jeden, co mnie dziadek nauczył z teatru, z przedstawienia Dybuk, drugi był «Spotkamy się na Nowym Świecie», a trzeci «Kinderjur», o siłaczu Brajtbardzie. Ostatnie najlepiej się podobało i musiałem czasem parę razy

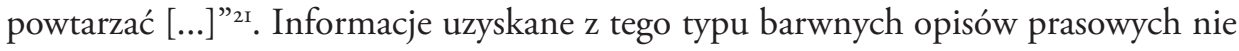
są pełne, ale rzucają nieco światła na to, co i jak grywało się w pierwszych dekadach XX w. w przestrzeni publicznej polskich miast.

Prasa to niezwykle interesujące źródło do badań nad twórczością muzyków ulicy, nie tylko w Polsce, lecz także w innych krajach. Australijski muzykolog Paul Watt prześledził notki poświęcone muzykom ulicy, jakie ukazały się w XIX w. w lokalnych gazetach. W wielu z nich, poza informacjami o miejscu gry, instrumentach czy zarobkach, wspominano także o repertuarze, na który składały się między innymi: Home Sweet Home, Larboard Watch, Swanee River, Old Tare, Who's Dat Knocking, Courting Down in Tennessee, Soldiers of the Queen, Sons of the Sea, Honeysuckle and the Bee, Negro Melodies, Holy City, Lost Chord, One Hundredth ${ }^{22}$.

Wiedzę o muzycznym folklorze miejskim - historycznym repertuarze polskich muzyków ulicy - czerpać można przede wszystkim z publikacji Bronisława Wieczorkiewicza $^{23}$, Janusza Wasylkowskiego ${ }^{24}$, a także Jerzego Habeli i Zofii Kurzowejej ${ }^{25}$ Należy jednak mieć na uwadze to, w jaki sposób autorzy ci rozumieli „ulicę”. Nie wszystkie bowiem zapisane przez nich utwory były wykonywane przez muzyków ulicy w otwartej przestrzeni publicznej. Autorzy, pisząc „uliczne”, mieli na myśli „powszechne”, „popularne”, „rozpoznawalne”. Określenie „lwowskie piosenki uliczne” w rozumieniu Jerzego Habeli i Zofii Kurzowej tylko w niewielkim stopniu dotyczyło utworów wykonywanych przez muzyków ulicy w przestrzeni publicznej:

Piosenki były wykonywane przez solistów lub zbiorowo w knajpach, w parkach, w domu, podczas różnego rodzaju zebrań towarzyskich przy - o ile było to możliwe - akompaniamencie harmonii, skrzypiec, gitary lub mandoliny. Piosenki stanowiły repertuar zespołów chórowych, różnego rodzaju orkiestr dętych: wojskowych, kolejarskich, strażackich i formowanych przez różnego rodzaju stowarzyszenia wykonujące tzw. muzykę placową (Platzmusik), tj. przeznaczoną do grania pod gołym niebem na placach, w parkach lub ogrodach. Piosenki lwowskie wykonywali też piosenkarze kabaretowi lub zatrudnieni w różnych lokalach rozrywkowych, a także żebrzący domokrążcy ${ }^{26}$.

Grajek Sierota vel Sandomir Icchak, „Grajek sierota”, Maty Przeglad: pismo dzieci i mtodzieży: tygodniowy dodatek bezptatny do nr 72 "Naszego Przegladu” 3 (1928) nr 9.

22 Paul Watt, „Buskers and Busking in Australia in the Nineteenth Century”, Musicology Australia 4I (2019) $\mathrm{nr}$ I, s. 29.

23 Bronisław Wieczorkiewicz, Warszawskie ballady podwórzowe. Pieśni i piosenki warszawskiej ulicy, opr. Zygmunt Wiehler, Warszawa I97I.

24 Janusz Wasylkowski, Piosenki lwowskiej ulicy. Antologia, Wrocław 1987; Janusz Wasylkowski, Lwowskie misztygatki, Warszawa 2000.

25 Zofia Kurzowa, Jerzy Habela, Lwowskie piosenki uliczne, kabaretowe i okolicznościowe do I939 roku, Kraków 1989.

26 Ibid., s. 68. 
Także współcześnie wspomina się o repertuarze czy kapelach ulicznych, mając na myśli bądź powszechność repertuaru, bądź też odwoływanie się do folkloru miejskiego, nawet jeśli dana grupa nie występuje w przestrzeni publicznej, tj. na ulicy ${ }^{27}$.

Warto zwrócić uwagę na fakt, że dawny, przedwojenny muzyczny folklor miejski polskich miast właściwy był przede wszystkim dla Lwowa i Warszawy. W pozostałych miastach miał raczej znaczenie marginalne; powojenny muzyczny folklor miejski związany był z kolei w szczególności z robotniczą Łodzią, przy czym był on eklektycznym zbiorem

[...] treści tradycyjnych, chłopskich - np. obrzędów, zwyczajów itp. - spotykamy tu infiltrację elementów z ówczesnej kultury masowej. Wyrażają się one adaptacją modnych szlagierów, używaniem na weselach strojów zapożyczonych z warstw miejskich i inteligenckich. Jednak niezależnie od warstwy wiejskiej i miejskiej znajduje się tu warstwa czysto robotniczego folkloru, zrodzonego i powstałego właśnie w tym konkretnym środowisku ${ }^{28}$.

Współcześnie muzyczny folklor miejski nadal jest obecny na ulicach miast, choć intensyfikacja jego występowania nie jest duża i często związana jest z okresową zmianą repertuaru muzyków ulicy - w Warszawie jest on wykonywany np. I sierpnia z okazji Narodowego Dnia Pamięci Powstania Warszawskiego. Relatywnie często w przestrzeni miejskiej daje się słyszeć folklor wiejski, zarówno polski, jak i obcy; więcej o tym zjawisku piszę poniżej.

Im dalej cofniemy się w badaniu historii zjawiska muzykowania ulicznego, tym bardziej dostrzegalne będzie, jak doniosłą rolę pełnili występujący w przestrzeni publicznej artyści: „[...] spora część muzycznego życia społeczeństwa europejskiego rozgrywała się nie w salach koncertowych, salach operowych czy kościołach, lecz na ulicach, gdzie wszyscy, niezależnie od swojego statusu czy zamożności, mogli partycypować w tego typu przyjemnościach" ${ }^{29}$. Dziś muzycy występujący w przestrzeni

27 „Choć Kapela nie była zespołem krążącym po podwórkach i uliczkach, niektóre pozycje z jej repertuaru stały się tak popularne, że zasłużyły na miano powszechnych mińskich piosenek ulicznych", Piotr Dorosz, Na Stasiowa nutę. Rzecz o Mińskiej Kapeli Matego Stasia i muzyce tradycyjnej wschodniego Mazowsza, Mińsk Mazowiecki 2018, s. I5. Z kolei Bożena Lewandowska pisze: „[...] czy istniejące dziś kapele podwórkowe są reprezentantem folkloru tradycyjnego czy może raczej należą już do folkloru rekonstruowanego bądź współczesnego? Trudno na to pytanie odpowiedzieć jednoznacznie. Biorąc pod uwagę sposób funkcjonowania, kontekst, to kapele uprawiające nadal styl muzykowania ulicznego stanowią rzadko już dziś spotykany folklor tradycyjny. Równocześnie jednak próba podtrzymywania tej tradycji poprzez festiwalową scenę, nawiązywanie w różny sposób do okresów wcześniejszych, powoduje, że patrzymy na kapele jak na reprezentantów folkloru rekonstruowanego. Zwłaszcza w sytuacji, kiedy próbują odtworzyć wcześniejszy, zastany repertuar, poddając go niejednokrotnie stylizacji poprzez odmienną od oryginalnej aranżację muzyczną”, Bożena Lewandowska, „Miasto w tradycji muzycznej folkloru miejskiego: kapele podwórkowe i ich piosenki", Journal of Urban Ethnology Io (2010), s. 25.

28 Bronisława Kopczyńska-Jaworska, Jadwiga Kucharska, Jan Piotr Dekowski, Folklor robotniczej Łodzi. Poktosie konkursu, Wrocław I976, s. 7.

29 Percy Scholes „Street Music”, w: The Oxford Companion to Music, red. John Owen Ward, LondonNew York-Toronto I970, s. 987. 
publicznej nie są już jednym z nielicznych kanałów transmisji muzyki ${ }^{30}$, często transmitują i wykonują to, co jest już powszechnie znane.

\section{REPERTUAR WSPÓŁCZESNYCH MUZYKÓW ULICY}

Z uwagi na efemeryczny charakter zjawiska muzykowania ulicznego, konieczne jest ciągłe dokumentowanie repertuaru wykonywanego przez artystów przestrzeni publicznych. Lista prezentowanych na ulicy utworów jest zmienna i zależy od tego, jaki kraj czy kragg kulturowy opisujemy. Nie jest powszechna i trwała, ale związana jest z konkretnym wykonawcą, przy czym muzycy ulicy ciągle aktualizują swój repertuar - niezwykle silny jest wewnętrzny imperatyw estetyczny i gust wykonawców, artyści uliczni wykonują to, co lubią, choć należy pamiętać również o tym, że wykonawcy skłonni są prezentować konkretne utwory, przewidując, że zachwycą tym publicznośćs ${ }^{3}$. Ponadto warto zwrócić uwagę na fakt, że utwory, które pojawiają się w przestrzeni publicznej, nie charakteryzują się spójnymi, wyróżniającymi je, odrębnymi cechami, stąd niemożliwe jest badanie repertuaru muzyków ulicy w ujęciu strukturalnym. Muzyka ulicy nie jest bowiem gatunkiem muzycznym, a wśród wykonawców spotykamy tych, którzy prezentują określoną muzykę, np. grają tylko jazz bądź wyłącznie folklor (miejski lub wiejski), jak i takich, którzy w swoim repertuarze mają utwory o różnej proweniencji.

Z uwagi na brak możliwości wyodrębnienia „pieśni ulicznej”, oznaczającej sumaryczny zbiór całego repertuaru wykonywanego w przestrzeni publicznej ${ }^{22}$, oraz na jednoczesną szeroką rozległość gatunkową i rodzajową prezentowaną przez muzyków ulicy, przy próbie scharakteryzowania repertuaru współcześnie prezentowanego w przestrzeni publicznej przyjąć należy podejście funkcjonalne. Dlatego do repertuaru muzyki ulicznej zaliczam utwory wykonywane przez muzyków ulicy podczas oddolnie zorganizowanego i samodzielnie zrealizowanego wykonania artystycznego w przestrzeni publicznej, którego celem jest występ przed publicznością. Tym samym wyłączam ze zjawiska muzyki ulicy utwory i wykonania prezentowane $\mathrm{w}$ trakcie odgórnie organizowanych wydarzeń na świeżym powietrzu, festiwali,

30 W haśle dotyczącym muzyki ulicy Ernst Weber zauważa, że „przez długi czas dla wielu warstw społecznych była ona [muzyka ulicy - przyp. E.G.] jedną z niewielu form muzyki, do której miały one dostęp”, Ernst Weber, „Strassen Musik”, w: Österreichisches Musiklexikon, Wien 2006, s. 2325.

3I Barbara James, „«Freiheit und Glück!» Strassenmusik heute. Ein Sänger und sein Repertoire”, Jahrbuch für Volksliedforschung 26 (1981), s. 78.

32 „Pieśń uliczną” rozumianą jako folklor miejski można scharakteryzować jako tę, której tekst nawiązuje „[...] do określonego miasta, nazywa dokładnie ulice, wymienia znane obiekty i realia miejskie, lubi cytować nazwiska osób w mieście znanych, nawiązywać do miejscowych wydarzeń i skandali, odzwierciedlać najświeższe wypadki historyczne, przez co nabiera niezwykłej aktualności politycznej. Co więcej, piosenka uliczna powstaje jako reakcja na każdą teraźniejszość miasta, stanowi żywy, spontaniczny, natychmiastowy oddźwięk na każde wydarzenie, które zdobyło w mieście pewien rozgłos, na każdą wieść lub plotkę, która zatoczyła szersze kręgi”, zob.: Z. Kurzowa, J. Habela, Lwowskie piosenki uliczne, s. 63. 
koncertów plenerowych, a także kompozycje wykorzystujące elementy pejzażu dźwiękowego z pobudek bądź w celach artystyczno-estetycznych, a niewykonywane w całości w przestrzeni publicznej. Wyłączeniu ulegają także wszelkie odtworzenia muzyki z głośników, bez jednoczesnej gry na instrumencie bądź śpiewu, jeśli jednak odtworzenie stanowi podkład muzyczny dla samodzielnie zrealizowanego wykonania artystycznego (występowanie z tzw. półplaybackiem), jest przeze mnie włączane do omawianego zjawiska.

Muzycy ulicy spotkani w trakcie przeprowadzonych badań terenowych ${ }^{33}$ najczęściej wykonywali utwory muzyki klasycznej, jazzowej, bluesowej, religijnej, tradycyjnej grup etnicznych bądź etnograficznych, a także folk oraz folklor miejski. We Francji z kolei, poza muzyką poważną, popem, jazzem, rockiem, country, rapem (m.in. rumuńskim), folkiem, reggae i muzyką eksperymentalną, usłyszeć można także muzykę świata (m.in. arabską), piosenkę francuską oraz tzw. piosenkę festiwalową̨ W literaturze niemieckiej nie została podjęta całościowa analiza repertuaru muzyków ulicy, ale dokumentowano utwory wykonywane przez poszczególnych artystów, np. repertuar Roberta K. utrwaliła Barbara James ${ }^{35}$. Repertuar współczesnych polskich muzyków ulicy częściowo został już scharakteryzowany ${ }^{36}$. Pod względem autorstwa wykonywanych w przestrzeni publicznej utworów wyróżnić możemy: twórczość anonimową, autorską oraz tworzoną przez innych autorów.

Utwory prezentowane w przestrzeni publicznej, dla których nie da się ustalić autorstwa, to najczęściej anonimowe kompozycje twórców ludowych. W trakcie badań terenowych, które przeprowadziłam w ramach pracy nad dysertacją doktorską, spotkałam

33 Przywoływane w niniejszym tekście wypowiedzi muzyków ulicy, jeśli nie zaznaczono inaczej, pochodzą z badań terenowych autorki, przeprowadzonych w trakcie przygotowywania rozprawy doktorskiej Artysta, performer, żebrak, por. przyp. I. Autorka przeprowadziła długotrwałe i wieloczynnikowe (realizowane przy użyciu przynajmniej dwóch różnych technik pozyskiwania informacji) badania terenowe, które miały charakter holistyczny i indukcyjny - na podstawie zebranych w terenie materiałów wysnuto wnioski i wypracowano obowiązujące wzory. W ramach przeprowadzonych etnograficznych badań terenowych istotnymi czynnościami w pozyskiwaniu informacji były: obserwacja (w tym także obserwacja uczestnicząca), rozmowy, wywiady, dokumentacja fotograficzna, rejestracje repertuaru w formie audio i zachowań scenicznych w formie audiowizualnej. Punktem wyjścia była zawsze obserwacja, często łączona z dokumentacją fotograficzną i rejestracją dźwiękową. W trakcie badań zastosowano także podejście emiczne, wykorzystując technikę obserwacji uczestniczącej - grając na drewnianym flecie poprzecznym, autorka występowała w różnych miastach, zarówno w kraju, jak i za granicą: na ulicach, w przejściach podziemnych, w metrze, co stanowiło behawioralny kontekst badań. Badania terenowe prowadzono od 20II do 2018 r., w szczególności w Polsce (Warszawa, Wrocław, Poznań, Pomorze Wschodnie i Zachodnie), w Wiedniu oraz w niemieckich miejscowościach uzdrowiskowych nad Morzem Bałtyckim leżących w bliskim sąsiedztwie Polski.

34 Joanna Dobrzańska, Muzyk uliczny w przestrzeni Montpellier, Sète i Paryża, Uniwersytet Warszawski 2016 (praca magisterska), s. 88.

35 B. James, „«Freiheit und Glück!»”, s. 77.

36 Ewelina Grygier, „O czym śpiewa ulica?”, w: Tubylcy wtasnego świata. W stronę antropologii bliskości, red. Waldemar Kuligowski, Wrocław 20II, s. I37-I48; tejże, „The Repertoire of Street Musicians in a Time of Globalisation”, w: Music Glocalization: Heritage and Innovation in a Digital Age, red. David Herbert, Mikołaj Rykowski, Cambridge 20I8, s. 27I-305. 
muzyków wykonujących muzykę: wielkopolską, podhalańską, z szeroko rozumianego rejonu Karpat, ukraińska, słowacka, szkocką, andyjską i inne. Dana muzyka regionalna prezentowana była zarówno in situ, była to zatem tzw. „muzyka miasta”, charakterystyczna i reprezentatywna dla danego regionu, związana z nim historycznie, jak również tzw. „muzyka w mieście” - twórczość przeniesiona i prezentowana w obcym kulturowo kontekście ${ }^{37}$, np. muzyka andyjska wykonywana w Polsce.

Tradycyjną muzykę regionu wielkopolskiego zaobserwowano na Starym Rynku w Poznaniu w wykonaniu grającego na dudach wielkopolskich Adama Knobla. Muzyk prezentuje tradycyjny wielkopolski repertuar, grając m.in. utwory $W$ sini dót czy Postata mnie matka na górę po jabtka. We Wrocławiu także muzykuje dudziarz, który gra na tzw. wielkich dudach szkockich (Great Highland bagpipe), wykonując utwory właściwe dla tego instrumentu: marsze szkockie oraz popularne melodie Amazing Grace i Scotland the Brave. W tym przypadku nie jest to więc „muzyka miasta” lecz „muzyka w mieście” ${ }^{8}$. Tego typu działania są charakterystyczne i coraz bardziej naturalne dla współczesnego świata, dziś bowiem, jak zauważa Wojciech Burszta, kultura ludowa „nie jest już związana terytorialnie ani z wsią, ani z konkretnymi regionami. Jest uniwersalną formą światopoglądu, który trwa w kulturze postindustrialnej"39.

Muzykę podhalańską prezentowała w Warszawie wykonująca tradycyjny repertuar trzynastoletnia skrzypaczka. Dziewczynka przyjechała do stolicy z ojcem, który nieopodal miejsca jej gry sprzedawał oscypki. Młoda skrzypaczka wykonywała m.in. nuty ozwodne Maty jo se maty oraz Jawory, jawory, Marsz generata Galicy „Ej tam spod Tater", nutę do zbójnickiego W murowanej piwnicy oraz nutę balladową - Duchową

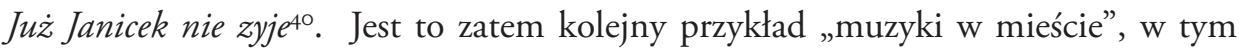
jednak przypadku wykonawczyni prezentowała muzykę tradycyjną z regionu, z którego pochodzi, inaczej niż wrocławski dudziarz, który wykonuje repertuar właściwy Szkotom, mimo że sam jest narodowości polskiej"

37 Robert Losiak, „Muzyka w przestrzeni publicznej miasta. Z badań nad pejzażem dźwiękowym Wrocławia”, w: Dźwięk w krajobrazie jako przedmiot badań interdyscyplinarnych. Prace Komisji Krajobrazu Kulturowego, red. Sebastian Bernat, Lublin 2008, s. 255.

38 Por.: ibid., s. 255. Dysponujemy także historycznymi wiadomościami dotyczącymi prezentowania regionalnego folkloru wiejskiego, tak w najbliższym regionie, np. dudziarze Michał Kulawiak czy Józef Ciszak grający na dudach wielkopolskich, występujący przed II wojną światową w przestrzeni publicznej w Poznaniu, jak i poza „naturalnym” kontekstem - instrumentaliści Jan Pajchrowski i Michał Rabiega prezentujący folklor wielkopolski na Pomorzu, por. Jadwiga Sobieska, Protokół nagrania o sygn. Po4IIA, nagranie i protokół ze Zbiorów Fonograficznych Instytutu Sztuki PAN (I95I r.).

39 Wojciech Józef Burszta, „Kultury Ludowej już nie będzie”, wywiad Łukasza Grzymisławskiego, Gazeta Wyborcza 20 (2008) z 8-9 III, s. II.

40 Za konsultacje w sprawie repertuaru góralskiego dziękuję dr Dorocie Majerczyk.

4I Muzyka celtycka szczególnie popularna była w Polsce w latach osiemdziesiątych XX w., choć dziś nadal istnieje wiele zespołów muzycznych i tanecznych wykonujących repertuar irlandzki bądź szkocki, rzadziej bretoński. Z fascynacją muzyką celtycką wiążą się początki rodzenia się ruchu folkowego w Polsce: „Dopiero pod koniec lat osiemdziesiątych istniejące zespoły grające muzykę andyjską, celtycką lub azjatycką zaczęły wykorzystywać polski folklor i polskie pieśni ludowe. Jest to bardzo znamienny zwrot [gdyż 
Folklor postrzegany jest jako twórczość całkowicie anonimowa, „dobro wspólne” przekazywane ustnie, z pokolenia na pokolenie, drogą uczestnictwa w kulturze, jak bowiem zauważa Aleksander Jackowski,

[...] tradycyjna kultura chłopska nie znała „twórców” czy „artystów” [...] nie znała ostrego podziału ról na „aktorów i widzów”. [W tej kulturze - E.G.], każdy mógł bez uprzedniej sankcji być zarówno twórcą, jak i konsumentem ${ }^{42}$.

Dzięki temu pomiędzy uczestnikami tworzyło się tzw. sprzężenie zwrotne, tak charakterystyczne dla folkloru. Wykonawcy folkloru, dziś chętnie nazywani depozytariuszami tradycji, traktowani byli jako swoiste media przekazujące, transmitujące wspólną, anonimową kulturę. Indywidualizm wykonawcy nie objawiał się zatem w kreowaniu (tworzeniu) muzyki, lecz jej artystycznym przetworzeniu - wykonaniu - skąd wywodzić można wariantywność jako jedną z podstawowych cech wykonawczych w muzyce tradycyjnej. Jednak należy pamiętać, że nie wszystko, co wydaje się być „tradycyjne”, zawsze jest anonimowe. Dobitnie podkreśla to socjolog Adam Czech:

[...] ponieważ zaś kultura chłopska miała być w domyśle takim spichlerzem [tradycji - przyp. E.G.] co najmniej od czasów Piasta Kołodzieja, należało dokonać ekwilibrystycznego zabiegu wymyślenia kuriozum poznawczego, jakim jest „stała, niezmienna i odwieczna” kultura ludowa („bryłka bursztynu”). Skutki tego widać do dziś nie tylko w potocznej recepcji całej kultury wsi (a więc również muzyki ludowej), lecz także często - niestety - w analizach naukowych [...] w przypadku rozważań na temat kultury ludowej mamy wciąż do czynienia z pewną kreacjonistyczną ideologią, zgodnie z którą Pan Bóg, stwarzając świat, musiał chyba zrzucić na ziemię sierp oraz fidel płocką i burczybas, a co więcej, podać dokładnie instrukcje ich użytkowania ${ }^{43}$.

Kultura i tradycja nie pozostają nigdy constans, zmieniają się nieustannie, choć nieraz z pozoru niezauważalnie. Tradycja jest stosunkiem współczesnych do spuścizny antenatów („cała przeszłość jest potencjalną tradycją”"44), a z uwagi na żywotny charakter kultury tradycyjnej, przenikały do niej autorskie treści, które nieraz z czasem, wraz z ich upowszechnianiem się, ulegały quasi-anonimizacji.

Wśród repertuaru muzyków ulicznych znaleźć można kilka kompozycji, które postrzegane są jako tradycyjne, mimo że z powodzeniem można przywołać ich twórców. To m.in. utwory Teraz jest wojna, Barka oraz Lot kondora (El condor pasa). O dwóch pierwszych piszę nieco później, teraz zatrzymajmy się przy znanej melodii południowoamerykańskiej. W powszechnej opinii, co potwierdzają rozmowy z muzykami

\footnotetext{
- przyp. E.G.] [...] często polskie zespoły folkowe rozpoczynały swoją drogę artystyczną od repertuaru pieśni kultur egzotycznych, przechodząc stopniowo w swym rozwoju do pieśni swojego regionu, a nawet mikroregionu", Tomasz Rokosz, Od folkloru do folku. Metamorfozy pieśni tradycyjnych we wspótczesnej kulturze, Siedlce 2009, s. 80-82.

42 Aleksander Jackowski, „Pojęcie twórcy ludowego”, Lud 64 (1980), s. 5.

43 Adam Czech, Sprzedawcy wiatru, Warszawa 2008, s. 17, 20.

44 Jerzy Szacki, Tradycja. Przeglad problematyki, Warszawa I97I, s. I4.
} 
ulicy, utwór ten uważany jest za melodię tradycyjną. Zamieszkały na stałe w Rumi Peruwiańczyk tak się wypowiada:

El Condor pasa to jest taka stara piosenka i mogę powiedzieć, że to jest nasza wizytówka, nie? Bo każdy, który słucha ta piosenka, mówią: to Peru! Tak, Peru. To jest fajne, nie? I ludzie po prostu bawią się i znają ta piosenka. Ja po prostu... ja uważam, że to, co ja robię, muszę być fajny, muszę być profesjonalne, bo ja w tej chwili, kiedy stoję na ulicy i robię, co robię, ja reprezentuje mojego kraju, to po prostu jest ogląd mojego kraju. Zachęcić ludzi, żeby kiedykolwiek będą mieć czas i trochę kasa, żeby do nas przyjechać, że u nas nie jest tak..., że my nie jesteśmy tak, że jesteśmy dziwny dla obcokrajowców, jesteśmy mili i otwarci dla obcokrajowi, jesteśmy bardzo ciekawa kultura, żeby mogą przyjechać do nas do Peru, do Boliwii, do Ameryka Łacińska ${ }^{45}$.

Mimo silnego umocowania w tradycyjnej kulturze, utwór El condor pasa (który, być może, jak chciałby tego mój rozmówca, jest muzyczną wizytówką Ameryki Łacińskiej i Peru) jest przede wszystkim autorską kompozycją, której twórcą jest peruwiański etnomuzykolog Daniel Alomía Robes (I87I-I942). El condor pasa to najsłynniejszy utwór tego autora, napisany w I9I3 r., będący częścią większego dzieła o tym samym tytule. Rozgłos melodii wzrósł dzięki duetowi Simon \& Garfunkel i zarejestrowaniu utworu na jego płycie Bridge over Troubled Water w 1970 roku. W tym popularnym nagraniu pobrzmiewają nawet fletnie pana. Obecnie niemal każdy występujący w Polsce zespół muzyków pochodzących z Ameryki Południowej ma w repertuarze kompozycję Robesa, a nieraz także jest ona wykonywana na specjalne życzenie publiczności. $\mathrm{Na}$ pytanie o to, czy ludzie podchodzą do muzyka i zamawiają u niego jakiś konkretny utwór, instrumentalista z Ameryki Południowej opowiada:

Oczywiście, że tak, i zawsze to samo. El condor pasa. Ja zawsze się cieszę, nie? Fajnie. Najfajniejsze to jest, wiesz, kiedy są lekko, delikatnie pijani, a ja już, lekko ze śmiechem, mówię: poczekajcie, poczekajcie, wszystko będzie, tylko że powoli [w swoim czasie przyp. E.G.].

Drugą kategorią, obok twórczości anonimowej, jest twórczość autorska. Całkowicie autorskie utwory wykonuje muzyk występujący pod pseudonimem The Mind Traveller. Spotkany w Warszawie artysta grał między innymi piosenki: The Girl Out There (napisana wspólnie z Peterem Davisem), Reboot Failure, Chanson de re-rupture, See You in Another Life czy Reconnection. Własne utwory gra też małżeństwo wiekowych podróżników prezentujących się publiczności jako Pilgrims of Freedom. Większość ze śpiewanych przez nich utworów została napisana w języku angielskim, wśród nich dominują teksty traktujące o wolności i miłości (do świata, do ludzi, do Boga): Wild Wind of Freedom, Sing Me Your Melody, Kiss Me One More Time. Rzadziej muzycy wykonywali piosenki w swoim rodzimym języku (So groß wie die Welt). W autorskiej twórczości Davida i Sheikinah dostrzec można prezencję ich własnej

Pisownia odzwierciedla oryginalny idiolekt udzielających wywiadów muzyków. 
wizji świata. Z kolei poznański muzyk uliczny Tadeusz Lis, obok repertuaru napisanego przez innych, z których najczęściej śpiewanym przez niego był Zegarmistrz światta purpurowy (Tadeusz Woźniak, Bogdan Chorążuk), wykonywał także swoją kompozycję - Blues dla bezdomnych, którą zarejestrował na płycie Poznań, nasze miasto.

Autorska muzyka ulicy powstaje także podczas improwizacji. Wielu z występujących w przestrzeni publicznej muzyków grywa tworzone ad hoc melodie: „są tematy, które gramy razem, a potem jest sama improwizacja, różne akompaniamenty, różne solówki" - wspomina francuski balafonista Maxime Piazza, mieszkający i występujący w Warszawie. Z kolei spotkany na placu Zamkowym wibrafonista zaznacza:

Głównie gram swoje rzeczy, swoje kompozycje gram, również improwizuję, częściej nawet improwizuję, bo jeszcze na tyle kompozycji nie mam, żeby zapewnić ludziom rozrywkę i sobie przy okazji, albo inaczej: sobie i przy okazji ludziom. No i pojawiają się takie również bardziej znane melodie, ale tego jest mało.

Znaczące miejsce wśród repertuaru muzyków ulicy zajmują utwory napisane przez znanych autorów bądź kompozytorów. Repertuar mieszkającego w Polsce Białorusina Valerego Gaydenki, grającego na gitarze klasycznej, składa się w znacznej mierze z utworów klasycznych: Pożegnanie ojczyzny Ogińskiego, Ave Maria Schuberta, Sarabanda z Suity klawesynowej nr 4 d-moll Händla (HWV 437). Białorusin chętnie prezentuje też utwory z repertuaru Napoléona Costy. Muzyka klasyczna jest dość często spotykana na ulicy, przy czym wykonawcy raczej nie prezentują całych utworów, lecz wykonują wybrane fragmenty z dzieł muzyki klasycznej, w tym na przykład fragmenty Czterech pór roku Vivaldiego, Marsza tureckiego Mozarta $^{46}$, Czardasza Vittoria Montiego czy beethovenowskiej Bagateli a-moll WoO 59 (Für Elise).

Warto wspomnieć, że część wyimków z muzyki klasycznej prezentowana jest także $\mathrm{w}$ trakcie szczególnych okresów $\mathrm{w}$ roku związanych z kalendarzem liturgicznym kościoła katolickiego. W okolicy świąt Wielkiej Nocy, I listopada oraz w okresie Świąt Bożego Narodzenia, mieszkańcy miast i wsi ze zwiększoną intensywnością udają się na cmentarze, by odwiedzić zmarłych. Wtedy też w nekropoliach pojawiają się muzycy uliczni, a rozbrzmiewające utwory to w szczególności muzyka klasyczna, np. bardzo popularne wśród wykonawców grających na cmentarzach są Bachowska Aria na strunie G oraz Ave Maria Schuberta.

Równie dużym zainteresowaniem jak muzyka klasyczna cieszy się szeroko rozumiana muzyka popularna. Wśród prezentowanych w przestrzeni publicznej dzieł usłyszeć można zarówno utwory popowe, jak i rockowe czy bluesowe: Highway to Hell grupy AC/DC, Hallelujah Leonarda Cohena, Znów jesteśs ze mną De Mono, Nie

46 Pewien spotkany w trakcie badań terenowych w Wiedniu akordeonista całymi dnia grał tylko i wyłącznie ten jeden utwór (muzyk nie zgodził się na udzielenie wywiadu). 
ptacz Ewka Perfektu, Dni, których jeszcze nie znamy Marka Grechuty, Englishman in New York Stinga, All My Loving The Beatles, Layla Erica Claptona, Sweet Home Alabama amerykańskiej grupy Lynyrd Skynyrd i inne. Prezentujący się w formie performansu repetytywnego ${ }^{47}$ zespół Red Heels wykonuje zawsze w niezmienionej kolejności sześć utworów, są to: Mission Imposible - muzyka do filmu pod tym samym tytułem (Danny Elfman, Lalo Schifrin), utwór Smooth Criminal z repertuaru Michela Jacksona, Bad Romance (Lady Gaga), Misirlou - zapowiadana jako „Bitwa na smyczki” grecka melodia, rozpowszechniona w szczególności jako ścieżka dźwiękowa do filmu Pulp Fiction, Smells Like Teen Spirit Nirvany, a na zakończenie Highway to Hell - cover grupy AC/DC.

W przestrzeni publicznej od czasu do czasu rozbrzmiewa także jazz, w tym największe przeboje tego gatunku, jak choćby np. Hit the Road Jack, When All the Saints Come Marching In Louisa Armstronga czy utwory z repertuaru Herbiego Hancocka: Chameleon i Cantaloup Island. Wykonujący je duet instrumentalistów (saksofon tenorowy, kontrabas) - studentów wrocławskiej Akademii Muzycznej widzi w wykonywaniu jazzu na ulicach szansę umuzykalnienia społeczeństwa i zapoznana go z wartościową muzyką: „Dobieramy repertuar pod kątem tego, żeby nam się w miarę fajnie grało i żeby ludzie przychodzili posłuchać [...] ja sobie dorobiłem taką filozofię do tego grania, że pokazujemy ludziom dobrą muzykę" - twierdzi jeden z instrumentalistów.

Wykonywanie utworów innych autorów wiąże się z możliwością wprowadzania zmian przez artystę, niezależnie od intencji twórcy utworu: Joanna Dobrzańska podaje, że „[...] 20 listopada I856 roku gazeta «Le Charivari» zrelacjonowała sytuację, w której Giacomo Rossini zszedł do jednego kataryniarza, by zwrócić mu uwagę, iż gra jeden z jego utworów zbyt wolno" 48 , częściej anegdota ta jest kojarzona jednak z Giuseppe Verdim:

Nie namyślając się długo, zeszedł Verdi na podwórze i skrzyczał kataryniarza, nakazując grać wolniej. Gdy ten nie okazał się skłonnym do posłuszeństwa, mistrz przedstawił się kataryniarzowi, który ze wzruszenia wypuścił korbę z ręki i pokornie zdjął z głowy kapelusz. Wtedy Verdi pochwycił korbę, zagrał parę taktów i powrócił do pracy. Jakież było zdziwienie twórcy Trubadura, gdy następnego dnia usłyszał arię we właściwym tempie. Chcąc przekonać się, czy wykonawcą był ten sam kataryniarz, Verdi wyjrzał przez okno i ku przerażeniu swemu zauważył na katarynce tabliczkę z napisem: „Uczeń Verdiego”49.

$47 \mathrm{Na}$ podstawie materiałów zgromadzonych podczas badań terenowych, inspirując się także regulacjami prawnymi (Tips for Street Performers, Huntington, Everhart 20I3), wyróżniam kilka odmian performansu muzyki ulicy. Z uwagi na sposób prezentacji materiału wyróżniam performans repetytywny, labilny oraz epizodyczny. Biorąc pod uwagę stopień organizacji miejsca gry oraz zastosowania pozamuzycznych technik, wyodrębniam performans statyczny i dynamiczny. Performans repetytywny, o którym mowa w tekście głównym, polega na kilkukrotnym, najczęściej oddzielonym przerwą, powtórzeniu przygotowanej struktury występu (kolejności utworów).

48 J. Dobrzańska, Muzyk uliczny, s. 29.

49 Feliks Halpern, Muzycy w anegdocie i humor muzyczny, Łódź 1929, 7-8. 
Warszawski kataryniarz Piotr Bot samodzielnie przygotowywał kolejne utwory „dziurkował”, czyli zapisywał utwory na taśmie perforowanej, mógł zatem nie tylko poszerzać swój repertuar, ale i równocześnie dostosowywać go do mody i okoliczności (np. grać kolędy i piosenki świąteczne w okresie bożonarodzeniowym). Jego leszczyński kolega Tadeusz Zajdowicz pozbawiony takiej możliwości, zmuszony jest wygrywać na swojej ponad stuletniej katarynce tylko to, co zostało na niej „zapisane” na etapie produkcji. Katarynka Zajdowicza, którą stworzyła w I879 r. berlińska firma Frati \& Co., posiada wbudowany na stałe drewniany walec z „nabitymi” melodiami. W zdecydowanej większości są to utwory autorstwa kompozytorów kręgu niemieckojęzycznego: pochodzące z operetki Der Bettelstudent walc Laura, galop Schwamm drüber oraz mazurek Die schöne Polin austriackiego kompozytora Carla Millöckera czy walc So wie du Ludolfa Waldmanna. Tadeusz Zajdowicz nie ma więc żadnego wpływu na to, jaki repertuar wykonuje.

Czy jednak ci wykonawcy, dla których instrument nie jest ograniczeniem, piszą własne piosenki i tworzą muzykę? Czescy śpiewacy na pytanie o to, czy komponują, odpowiedzieli:

Nie, przerabiamy tylko pieśni zgodnie z naszymi potrzebami. Wyszukujemy na przykład w pieśni słowa, które wydają nam się niezrozumiałe i zamieniamy je innymi. Przede wszystkim w języku mówionym sporo się zmieniło. Musimy dopasowywać słowa do współczesnych czasów, ponieważ jeśli tekstów nikt nie zrozumie, wtedy to nie będzie miało sensu. Często zdarza się także, że poprawiamy teksty zgodnie z prawdziwymi wydarzeniami historycznymi [...] Melodie tylko częściowo zmieniamy, tylko nieznacznie. Na przykład dla jakiegoś wersu są trzy melodie, które można używać zamiennie ${ }^{50}$.

Także występujący w Polsce białoruski gitarzysta Gienek Loska przerabiał teksty znanych utworów w trakcie wykonywania ich w przestrzeni publicznej ${ }^{j \mathrm{r}}$, ,ja chcę pokazać, że można to inaczej zagrać. W tym, jak grałem tutaj, przerobiłem tekst. Trochę upolityczniłem, ale i tak było zabawnie" - wyjaśniał muzyk w udzielonym mi wywiadzie. Od małych przeróbek jest już niedaleka droga do zjawiska pośredniego pomiędzy wykonywaniem utworów obcych autorów a twórczością własną - kontrafaktury. Zjawisko to było szczególnie często spotykane dawniej² ${ }^{2}$, współcześnie sporadycznie

50 Lubomír Tyllner, Musikalische Volkskultur in der Stadt der Gegenwart am Beispiel der Strassenmusikanten Stanislav Gana und Erika Babincová in Prag. Ceské lidové pisne a balady, transkrypcja wywiadu z dn. 3 VI 1998 r., Universität Passau 1998 (materiał niepublikowany).

5I Muzyk stał się rozpoznawalny dzięki udziałowi w jednym z telewizyjnych programów muzycznych (X Factor). Niestety, zmarł 9 IX 2020 r. po długiej chorobie; wywiad z nim został przeprowadzono trzy lata przed wystąpieniem u niego poważnych komplikacji zdrowotnych.

52 Kontrafaktury tekstowe charakterystyczne były w szczególności dla pieśni nowiniarskich sprzedawanych w formie tzw. druków ulotnych. Utwory te wykonywane były przez sprzedawców oferujących owe druki z konkretnymi „nowymi” pieśniami, choć najczęściej nowy był wyłącznie tekst utworu, a melodia pozostawała „znana”, stąd często umieszczano na drukach informację o tym, na jaką melodię należy śpiewać daną pieśń, zob.: Piotr Grochowski, Straszna zbrodnia rodzonej matki. Polskie pieśni nowiniarskie na przetomie XIX i XX wieku, Toruń 2010, s. 96-98. 
zdarza się, że na ulicy wykonywane są kontrafaktury. W Niemczech są to np. piosenki polityczne $^{53}$. Najbardziej interesującym utworem tego typu zarejestrowanym przeze mnie w przestrzeni publicznej pod koniec kwietnia 20 o r., jest pieśń Samolot zaraz wracać miat z autorskimi słowami wykonawcy - gitarzysty i wokalisty Wiesława Kuszewskiego, napisanymi do muzyki Leonarda Cohena Hallelujah ${ }^{54}$. W utworze tym autor opisuje tragiczny lot prezydenta Lecha Kaczyńskiego na obchody uroczystości rocznicy zbrodni katyńskiej, który wraz z innymi osobami zginął w wypadku tegoż samolotu. Tekst Kuszewskiego potraktować można jako swoistego rodzaju współczesną pieśń nowiniarską. Napisany przez warszawskiego gitarzystę utwór posiada bowiem następujące cechy zbieżne z tego rodzaju utworami: narracyjność, aktualność zdarzenia (w momencie napisania i wykonywania pieśni), niecodzienność i sensacyjność tematu, „którym są wydarzenia polityczno-militarne, społeczno-obyczajowe, kryminalne oraz różnego rodzaju klęski żywiołowe i katastrofy (powodzie, pożary, trzęsienia ziemi)" "55; ponadto utwór zawiera niemal wszystkie komentarze narratora charakterystyczne dla pieśni nowiniarskich: uogólniające, interpretujące oraz emocjonalne, zabrakło jedynie komentarza moralizatorskiego ${ }^{56}$.

Układanie do znanych melodii nowych słów odnoszących się do aktualnych wydarzeń stosunkowo często było związane z muzyką ulicy. Leon Kałtenbergh zauważa, że melodie wygrywane przez katarynkę były podłożem, na którym powstawały nowe utwory. Autor wymienia m.in. Tańce węierskie Brahmsa oraz „nutę jednego ze straussowskich walczyków”, do których na początku XX w. dopisywano teksty ${ }^{57}$. $\mathrm{Z}$ kolei w jednym z artykułów prasowych z lat dwudziestych odnajdujemy na poły zabawną, na poły tragiczną (z perspektywy służącej) historię o podkładaniu pod oryginalny tekst nowych słów o miłości:

Łódź, I6 sierpnia [I927 r. - przyp. E.G.]. Petronela Marjanikówna, służąca, korzystając z wyjazdu swych chlebodawców, zaprosiła do siebie koncertowy duet podwórzowy, jazz-bandzistę i kataryniarza, Józefa Berkowicza i Aleksandra Znamojeckiego. Muzykanci przynieśli z sobą wódkę, panna Petronela zaś przygotowała zakąski. Wieczór był nader urozmaicony. Znamojecki grał na katarynce, młoda para zaś tańczyła charlestona. Po każdym tańcu dla rozgrzewki raczono się wódką [...]. Libacja przeciągnęła się do godziny drugiej w nocy. Daremnie dziewczyna prosiła ich, by poszli do domu. [...] Gdy o godzinie 5 rano państwo K. powrócili do domu, Berkowicza już nie było. Petronela spała kamiennym snem i nie słyszała nawet, że otworzyli kuchenne drzwi. Tylko w sypialni paliło się światło. Znamojecki na małżeńskim łóżku umieścił katarynkę i w stroju niezbyt etykietalnym rozkoszował się muzyką: Petronelo, ja cię też kocham - śpiewał na melodie „Czardaszki”, „Bajadery” i „Ja się boję sama spać”. Gdy ujrzał p[aństwo] K. natychmiast

53 B. James, „सFreiheit und Glück!»”, s. 84-86.

54 E. Grygier, „O czym śpiewa ulica?”, s. I43-I44.

55 P. Grochowski, Straszna zbrodnia, s. II6.

56 Por.: ibid., s. I32-133.

57 Leon Kałtenbergh, „Muzyka na Starym Mieście”, Stolica I5 (1960) nr 39, s. I2. 
porzucił katarynkę i wskoczył na okno. - Złodziej! Łapać go! Zawołał pan K. Znamojecki wskoczył na bruk uliczny, lecz po chwili został schwytany. W komisariacie po krótkim dochodzeniu zwolniono go i zwrócono mu katarynkę. Tylko p. Petronela straciła posadę ${ }^{58}$.

Dawniej folklor miejski, którego część z pewnością wykonywana była w przestrzeni publicznej, często był tworzony jako kontrafaktura tekstowa. Podobnie jak w przypadku muzyki tradycyjnej, często także folklor miejski potocznie postrzegany jest jako anonimowy, jednak w przypadku wielu popularnych pieśni bez problemu można ustalić ich autorstwo. Utwór Teraz jest wojna udało mi się zarejestrować w dwóch wersjach językowych - polskiej kontrafakturze w wykonaniu Orkiestry z Chmielnej oraz w jego oryginalnej wersji językowej, w wykonaniu duetu dwóch instrumentalistów, którzy umilali czas publiczności siedzącej w kawiarnianych ogródkach na ulicy Freta, śpiewając utwór Teraz jest wojna w języku hiszpańskim - jako Cielito lindo. Niewiele bowiem osób słuchających na ulicy polską wersję językową domyśla się pochodzenia pieśni. Cielito lindo to meksykański utwór, napisany w I882 r. przez Quirino Mendozę y Cortésa ${ }^{59}$.

Podobny casus przedstawia pieśń Barka reprezentująca, jako jedna z nielicznych, muzykę religijną w przestrzeni publicznej. Podczas przeprowadzonych wywiadów z muzykami ulicy trzykrotnie zetknęłam się z tym utworem prezentowanym publicznie: w wykonaniu zespołu muzyków południowoamerykańskich spotkanych w Jastarni, w wykonaniu Boliwijczyka Noe G. Sancheza na co dzień mieszkającego w Czechach, a w okresie wakacyjnym występującego w Międzyzdrojach, a także romskiego pianisty Latifa Ispira, ucznia szkoły muzycznej w rumuńskich Botoszanach, także od kilku lat grywającego w czasie wakacji nad polskim morzem ${ }^{60}$. Nieznajomość skomplikowanych losów utworu i traktowanie pieśni jako związanej z papieżem Janem Pawłem II wpływać może na błędne interpretowanie jej pochodzenia. Barka często postrzegana jest jako anonimowa polska pieśń religijna, tymczasem bez problemu można ustalić jej twórców oraz proweniencję, o której jednak nie wiedzą nieraz najwyżsi rangą kapłani w Kościele katolickim. Otóż papież Jan Paweł II wielokrotne odbywał pielgrzymki do Ameryki Południowej. Podczas jednej z duszpasterskich wizyt w Peru usłyszał Barkę, co wzbudziło ogromne zdziwienie zarówno jego samego, jak i towarzyszącej mu świty. Jak relacjonował ksiądz Adam Boniecki: „ludzie uważnie wpatrzeni w Papieża, klaszczą, śpiewają (m.in. "Barkę», co zupełnie zdumiewa, gdzie ta nasza "Barka» trafiła), ale są cisi, pokorni, przejęci"6r. Postrzegana jako polska religijna pieśń, Barka jest w rzeczywistości kontrafakturą tekstową południowoamerykańskiej pieśni Pescador de Hombres (Rybak ludzi), którą w 1979 r.

58 „Petronelo, ja cię kocham”, Express Wieczorny Ilustrowany 5 (I927) z I6 IX, s. 3.

59 Weronika Grozdew-Kołacińska, Śpiewnik dawnej Warszawy, Warszawa 20I2, s. I48-I49.

60 Por.: Ewelina Grygier, „Uliczny pianista łamiący stereotypy”, Gadki z Chatki. Pismo Folkowe 4 (2014) nr II4, s. 26-27.

6I Adam Boniecki, „25. podróż Jana Pawła II. Papież w Peru”. Tygodnik Powszechny 4 I (1985) nr 9 z 3 III, s 2-3. 
skomponował Cesáreo Gabaráin. Polską wersję językową stworzył salezjanin Stanisław Szmidt. Jako pieśń popularna kojarzona z Polską w przestrzeni publicznej przez muzyków ulicy zapowiadana jest jako „ulubiona pieśń papieża Polaka” (południowoamerykański zespół z Jastarni), bądź tytułowana na wydawnictwach płytowych właśnie jako Barka (Liubomyr Bogoslavets, Boże, coś Polskę... Pieśni patriotyczne). Przypadek Barki jest zatem ciekawym przykładem glokalizacji.

Wątek nieznajomości autorstwa nasuwa kolejny trop odnoszący się do utworów wykonywanych w przestrzeni publicznej, mianowicie kwestię praw autorskich. We Francji, w której istnieją liczne przepisy dotyczące muzykowania ulicznego, „podczas wykonywania utworów innych twórców, do których prawa jeszcze nie wygasły, bez względu na to, czy jest to indywidualna prezentacja utworu podczas gry na ulicy, czy wykonanie podczas zbiorowego wydarzenia, należy posiadać licencję SACEM"62. W Polsce nie spotkałam się z takimi regulacjami, tym samym twórcy wykonywanych na ulicy dzieł pozbawieni są wynagrodzenia, przysługującego im z tytułu praw autorskich.

Dzięki powszechnemu dostępowi do mediów oraz procesom globalizacyjnym w wielu krajach usłyszymy te same utwory wykonywane przez muzyków ulicy. Wśród najbardziej popularnych kompozycji wymienić można w szczególności:

- Bésame mucho (Consuelo Velázquez),

- Tico-Tico no fubá (Zequinha de Abreau),

- Ave Maria (Franciszek Schubert),

- Hallelujah (Leonard Cohen),

- Valurile Dunării (Iosif Ivanovici),

- Rondo alla Turca (Wolfgang Amadeusz Mozart),

- O Sole mio (Giovanni Capurro, Eduardo Di Capua),

- Cztery pory roku (Antonio Vivaldi),

- Bagatela a-moll (Für Elise, Ludwig van Beethoven),

- Czardasz (Vittorio Monti),

- Stairway to Heaven (Led Zeppelin),

- When the Saints Go Marching In (Louis Armstrong).

Ewa Kofin podkreśla, że standaryzacja repertuaru związana z powszechnie dostępnymi nagraniami propagowanymi przez nowoczesne media dotyczy w znacznej mierze repertuaru rozrywkowego ${ }^{63}$, chociaż nie ulega wątpliwości, że także mniejsze fragmenty dzieł muzyki klasycznej należą dziś do kanonu popkultury

62 SACEM, Société des Auteurs, Compositeurs et Éditeurs de Musique (Stowarzyszenie Autorów, Kompozytorów oraz Wydawców), J. Dobrzańska, Muzyk uliczny, s. 53. Płyta francuskiego wokalisty i gitarzysty ulicznego The Mind Traveller - See You in Another Life, którą nabyłam od muzyka w trakcie jego koncertu ulicznego nieopodal Pałacu Kultury i Nauki w Warszawie, zawiera logo SACEM.

63 E. Kofin, Muzyka wokót nas, s. 49. 
i często są także obecne w repertuarze muzyków ulicy. Podobne zjawiska, choć w innym kontekście i mniejszej skali, wywoływało w XVI w. wynalezienie druku, w którego efekcie nastąpiło rozpowszechnienie się repertuaru muzycznego na szeroką skalę: „unifikacja repertuarów europejskich, a zarazem wzmagane przez druk poczucie odrębności miały znaczenie dla wzrostu erudycji autorów, którzy z jednej strony łatwiej asymilowali obce style, z drugiej - silniej odczuwali oryginalność swoich dzieł czy też muzyki najbliższych im kręgów twórczych" ${ }^{64}$. Ujednolicenie wykonywanych utworów widoczne jest także w repertuarze zarejestrowanym na płytach CD, o których piszę poniżej.

\section{CHARAKTERYSTYKA WSPÓŁCZESNYCH WYDAWNICTW PŁYTOWYCH}

Rozwój fonografii wpłynął na pozorny wzrost egalitaryzmu wśród muzyków. Praktycznie każdy zainteresowany może dziś sam nagrać płytę, jednakże nie każdy krążek wyprodukowany samodzielnie spełniać będzie cechy wydawnictwa profesjonalnego. Niemniej jednak możliwości istnieją i wielu z muzyków ulicy chętnie z nich korzysta: część z występujących w przestrzeni publicznej artystów zarejestrowało wykonywaną przez siebie muzykę na płytach CD bądź - rzadziej - DVD. W ramach działalności muzyków ulicy powstaje obecnie wiele wydawnictw, które nie są nigdzie skatalogowane. Duża liczba płyt jest po części efektem nieograniczonego dostępu do sprzętu rejestrującego, darmowych programów muzycznych, graficznych i domowych drukarek. Ze względów ekonomicznych nie wszyscy wykonawcy zdecydowali się na zarejestrowanie materiału w studio nagraniowym i zatrudnienie profesjonalnego reżysera dźwięku, a wielu z nich wybierało model produkcji domowej, leżącej w zasięgu ich finansowych możliwości ${ }^{65}$, bowiem dzięki dostępności sprzętu i oprogramowania, każdy ma możliwość stworzyć własną płytę; już w połowie lat osiemdziesiątych XX w. Mieczysław Kominek zauważył, że „[w]obec swojej rosnącej wciąż popularności, związanej z rozwojem techniki, fonografia staje się jednym z najważniejszych kanałów pobudzania kulturowej aktywności społeczeństw" ${ }^{\prime 6}$. Jednocześnie łatwość produkcji sprawia, że albumy nagrywają nie tylko profesjonaliści, lecz również amatorzy. Rezultatem tego jest bardzo zróżnicowana jakość wydawnictw,

64 Paweł Gancarczyk, Muzyka wobec rewolucji druku. Przemiany w kulturze muzycznej XVI wieku, Toruń 2OII, s. 263-264.

65 W erze przedfonograficznego powielania utworów w postaci druków muzycznych finanse także odgrywały ogromną rolę: „,...] druki musiały uwzględniać gusta i oczekiwania wielu nabywców. Wymagało to od drukarzy i wydawców podejmowania trudnych decyzji co do wyboru treści i formy księgi, które zawsze - w mniejszym czy większym stopniu - miały podłoże ekonomiczne [...] Drukarze i wydawcy musieli starannie dobierać repertuar, licząc na zainteresowanie odbiorców, i racjonalnie dysponować wydatkami na czcionki, papier i siłę roboczą. Wywierało to określony wpływ na postać zewnętrzną publikacji, która miała satysfakcjonować możliwie wielu klientów, a jednocześnie nie generować zbyt wysokich kosztów", ibid., s. IO5

66 M. Kominek, Zaczęto się od fonografu, s. 235. 
zarówno pod względem muzycznym (wykonanie), jak i technicznym (produkcja). Muzyk Tadeusz Lis tak opowiadał o swojej płycie:

[...] 500 sztuk zarejestrowałem, płytę pod tytułem Poznań, nasze miasto, nie stać mnie na edycję $\mathrm{i}$ ta płyta była tutaj robiona $\mathrm{w}$ takich biednych warunkach komputerowo-kuchennych, no i po prostu tej płyty nie jestem w stanie sprzedawać, teraz jestem w trakcie, robię następną płytę, bardziej ciekawszą, przy współpracy kolegi artysty muzyka, to jest Zaradny, January Zaradny.

Niestety, zanim kolejna płyta ujrzała światło dzienne, muzyk zmarł.

Wiele spośród wydawnictw proponowanych słuchaczom przez muzyków ulicy nosi znamiona „domowych” produkcji. Na podstawie zebranego materiału wyróżniam następujące cechy amatorskich wydawnictw płytowych oferowanych przez muzyków ulicznych:

- materiał zarejestrowano w domu (rzadziej w studiu nagraniowym),

- projekt graficzny wykonano we własnym zakresie,

- okładkę wydrukowano na drukarce domowej,

- płyty wytłoczono w domu,

- nie zarejestrowano wydawnictwa w organizacji zbiorowego zarządzania prawami autorskimi,

- nie podano wielu zwyczajowych informacji, np. informacji o miejscu i dacie nagrania, inżynierze dźwięku, informacji o artyście, tytułu bądź kontaktu i in.,

- w spisie utworów występują błędy w zapisie tytułów utworów i nazwisk kompozytorów,

- poziom jakości użytych materiałów jest zróżnicowany,

- sprzedaż płyt jest nieopodatkowana,

- albumy płytowe są wydawane nakładem samych muzyków lub - rzadziej - nakładem wydawnictwa.

Warto zauważyć, że cechą mocno różnicującą proces powstawania płyt amatorskich i profesjonalnych jest multispecjalizacja wykonawcy. Muzyk ulicy jest nie tylko artystą muzykiem (kompozytorem, aranżerem, wykonawcą). Często jest równolegle także nagrywającym, producentem, grafikiem, drukarzem, dostawcą materiałów, wydawcą, specjalistą od reklamy i sprzedawcą w jednej osobie. Konieczność wykonania tak wielu zadań z pewnością wpływać musi niekorzystnie na jakość płyty. Trudno wymagać od jednej osoby, by wykonywała perfekcyjnie pracę z tak różnych dziedzin. Imperatyw wielozadaniowości przy produkcji płyty podkreślał w wywiadzie jeden z warszawskich gitarzystów:

- Wydałem płytę rok temu swoją, się nazywa Natural Beat [...], ale jeśli chodzi o jakieś takie rzeczy archiwalne, coś tam gdzieś jest... tylko to się działo w takich czasach, kiedy nie było takiej swobody dostępu do studia. Zresztą samo to, żeby kupić jakąś normalną gitarę, to był jakiś kosmos.

- [E.G.:] A tę płytę też sprzedajesz na ulicy czasami? 
- Wiesz co, właśnie skończył mi się nakład, bo ja ją sam, w ogóle, wiesz, zrobiłem. Kupiłem płyty do nadruku, kupiłem taką specjalną drukarkę, i cały nakład w zasadzie poszedł. I później drukarka mi się popsuła i wiesz...

- [E.G.:] Czy sprzedawałeś tę płytę na ulicy?

- Nie, nie sprzedawałem. Jak mi ktoś dał na przykład jakąś większą kasę albo był jakąś fajną osobą, to dostawał tę płytę w prezencie.

Rumuński cymbalista Georg Leonard, zachwalając swoją płytę, podkreśla, że jest to nagranie profesjonalne (w domyśle: studyjne). Mimo tego, że muzyk jest wybitnym wirtuozem swojego instrumentu, absolwentem uczelni wyższej, a materiał zawarty na płycie został profesjonalnie wykonany oraz zarejestrowany, płyta nie ma nadruku na krążku i opatrzona jest wyłącznie wydrukowaną amatorską okładką zatytułowaną Georg Leonard - Virtuoso of the Cimbalom ${ }^{67}$. Na okładce znajduje się zdjęcie muzyka wraz ze spisem dziewięciu zarejestrowanych utworów i kontaktem wykonawcy. Mimo profesjonalnej rejestracji, płyta nie została nigdzie oficjalnie wydana i można ją kupić wyłącznie u grającego na ulicy rumuńskiego cymbalisty (cena płyty w 2012 r. wynosiła 20 złotych). Na słuchacza wkładającego album do odtwarzacza czeka także mała niespodzianka, okazuje się bowiem, że krążek zawiera dziesięć a nie dziewięć wypisanych na okładce utworów. Ostatni utwór nie został ukryty, nie jest więc to tzw. hidden track, lecz pełnoprawny numer, pominięty w spisie nagrań. W dodatku w nagraniach wziął udział nie tylko sam cymbalista, lecz także towarzyszący mu rozbudowany zespół instrumentalny. Zupełnie inne zaskoczenie czeka nas po włożeniu do odtwarzacza CD płyty The Mind Traveller - See You in Another Life. $\mathrm{Na}$ okładce albumu znajdziemy spis zarejestrowanych nagrań. Tekst wyświetlany w odtwarzaczu multimedialnym zawiera inne (być może pierwotne, robocze) nazwy utworów, niż te wydrukowane na kartonikowej okładce.

Tylko na nielicznych okładkach płytowych podano czas trwania poszczególnych utworów. Informację tę znajdziemy w następujących wydawnictwach oferowanych przez wykonawców ulicznych: Polskie pieśni patriotyczne Liubomyra Bogoslavetsa, płycie Gedrehte Ohrwürmer duetu niemieckich kataryniarzy, działającego jako Die Biermänner, oraz albumach Lecha Skawińskiego Skarbczyk retro tang i walców, Bukiet niezapominajek, To i owo na jazzowo. Wyłącznie płyta Jeannette i Petera Biermannów zawiera informację o całkowitym czasie trwania. Niekiedy na okładach płyt poszczególnych muzyków ulicy podawane są bardziej szczegółowe informacje o utworach i ich twórcach, czego dowodzą wydawnictwa Sergiusza Borshcha (albumy bez tytułu) czy album Heleny Borshch zatytułowany Koncerty smyczkowe. Obydwoje skrzypków zarejestrowało pieśn Ave Maria Schuberta, z tym że Sergiusz Borshch podaje pisownię nazwiska jako „Shubert”, a Helena Borshch jako „Schubert”.

67 Tego typu tytuł świadczy nie tylko o informacyjnej, lecz przede wszystkim reklamowej funkcji okładki, por.: ibid., s. I23. 
W obu przypadkach zaznaczone jest, że Polonez to utwór „Oginskiego” (zapis bez imienia i znaków diakrytycznych). Błędów w zapisach nazwisk i tytułów utworów jest więcej. Nazwisko Camille Saint-Saëns na płycie Sergiusza Borshcha zapisane jest jako „Sen-Sans”. Z kolei Helena Borshch utwór Tico-tico zapisała jako Tiko-tiko. Często pojawiają się różne zapisy fonetyczne. U Heleny Borshch spotkamy Czardasz, a u Sergiusza Borshcha Chardash. Znajdziemy też literówki, np. Gupsy song zamiast „gypsy” u Sergiusza Borshcha. Przy niektórych utworach w ogóle nie został podany autor. Ponadto płyta Heleny Borshch nie ma ustalonego schematu w podawaniu podstawowych informacji. Raz podany jest tytuł utworu, a w nawiasie kwadratowym wpisane nazwisko kompozytora: „Cztery pory roku - Lato [Vivaldi]”, innym razem autor figuruje pierwszy, a w nawiasie kwadratowym znajduje się szczątkowa informacja o utworze: „Vivaldi [Zima]”; widać zdecydowany brak konsekwencji w opisywaniu utworów. Zdarzają się także takie przypadki, kiedy autor utworu w ogóle nie zostaje uwzględniony w opisie ${ }^{68}$.

Wiele z płyt muzyków ulicy to kompilacje zawierające utwory reprezentujące bogaty repertuar. Jeden z utworów na płycie Marzenia o mitości V. Gaydenki zatytułowany jest Popuri (właśc. potpourri), gdyż sam w sobie jest składanką. Kompilacje różnych gatunków muzycznych znajdziemy między innymi na płytach skrzypka Sergiusza Borshcha (wydawnictwa bez tytułu). Na każdy z jego albumów składają się przeboje muzyki popularnej, np. Bésame mucho czy temat Chi Mai Ennia Morricone z filmu Georgesa Lautnera Zawodowiec (u Borshcha jako Morricone - Zawodowiec) oraz wyimki z muzyki klasycznej (kompozycje Dvořáka, Schuberta czy Paganiniego). Z kolei warszawski kataryniarz Piotr Bot tak reklamuje oferowane przez siebie wydawnictwa: „tam jest ponad godzina muzyki na każdej. Są dwie, jeszcze jest jedynka, tu jest dwójka [...] Troszkę klasycznej muzyki tam jest też, jest troszkę warszawskiej, polskiej”.

Wśród wydawnictw muzyków ulicy znajdują się także płyty sprofilowane repertuarowo i gatunkowo. Kielecki akordeonista Lech Skawiński nagrał trzy płyty, z których każda ma odrębny profil repertuarowy. Pierwsza nosi tytuł Treasury of Old Tangos \& Waltzes Retro (Skarbczyk retro tang i walców), druga to Bouquet of „Forget-me not's” (Bukiet niezapominajek), a ostatnia zawiera Some Various Pieces in Jazz Style (To i owo na jazzowo). Muzycy z Ameryki Południowej spotkani w Jastarni mieli w sprzedaży płytę wyłącznie z muzyką religijną, zatytułowaną Ave Maria. Ulubione pieśni religijne papieża Jana Pawta II na fletni pana (na okładce umieszczono pogrążonego w modlitwie Karola Wojtyłę). Na płycie, oprócz wspominanej już wyżej Barki, znalazły się m.in. Kwiaty polskie, Czarna Madonna, Drohiczyn, Wadowice i Ave Maria. Z kolei małżeństwo niemieckich kataryniarzy, oprócz płyty z wiązanką potpourri, nagrało także płytę z utworami klasycznymi, które częściej niż podczas występów ulicznych wykonywane są przez nich podczas koncertów w świątyniach.

Por.: ibid., s. II6. 
Ciekawym wydawnictwem jest płyta Liubomyra Bogoslavetsa Boże, coś Polskę... Pieśni patriotyczne. Zamieszczone na niej utwory - poza utworem tytułowym, także Rota, Jak to na wojence tadnie, Mazurek Trzeciego Maja, Ptynie Wista, ptynie, Dnia pierwszego września, Marsz Mokotowa, Siekiera, motyka, Patacyk Michla, Sanitariuszka Matgorzatka, Barka i kilka innych - wykonywane są przez ukraińskiego akordeonistę w szczególności I sierpnia z okazji Narodowego Dnia Pamięci Powstania Warszawskiego. Wewnętrzna strona okładki ${ }^{69}$ zawiera niepodpisane zdjęcie ruin, znad których tli się jeszcze ogień, co z pewnością ma podkreślić związek płyty ze wspomnianą rocznicą. Przykład Bogoslavetsa, nazywanego przez niektórych „prawdziwym Polakiem" (zapewne z uwagi na dostosowanie repertuaru do okoliczności), pokazuje dobitnie, jak funkcjonuje współcześnie repertuar muzyków ulicy. Często ci, którzy przybywają z zagranicy, starają się dostosować do lokalnych uwarunkowań kulturowych (stąd między innymi taka popularność Barki wśród występujących w Polsce wykonawców ulicznych, choć, jak wspomniano, ten przypadek, z uwagi na pochodzenie utworu, jest złożony). Podobne działanie uwidacznia się na płycie Al Compas De Los Sentimentos Noe G. Sancheza. Mieszkający w Republice Czeskiej Boliwijczyk niezwykle często występuje w Polsce, stąd na wydanej w $201 \mathrm{r}$ r. przez wydawnictwo El Sikuri płycie znalazły się takie utwory jak Taka mata, Lipka, czy piosenki z repertuaru zespołu Budka Suflera Jolka, Jolka pamiętasz oraz Bal wszystkich świętych. Główna linia melodyczna utworu Jolka, Jolka pamiętasz (u Sancheza utwór nosi tytuł Jolka Jolka), śpiewanego w oryginale przez Felicjana Andrzejczaka, tu została zagrana na fletni pana. Użycie tradycyjnych instrumentów, niezależnie od wykonywanego repertuaru, sprawia, że twórczość muzyków pochodzących z Ameryki Południowej jest spójna brzmieniowo. Niezwykle znaczący jest fakt, że albumy z wydawnictwa El Sikuri sprzedawane są przez muzyków ulicy także wtedy, kiedy oferujący je wykonawcy nie zostali zarejestrowani na żadnej z płyt. Sytuacja ta wyróżnia grupę wydawnictw muzyki południowoamerykańskiej wśród pozostałych albumów dostępnych w przestrzeni publicznej. Nagrania zawarte na płytach El Sikuri często są związane z muzykami jedynie pośrednio. Okoliczności te nasuwają skojarzenia z historyczną sprzedażą druków ulotnych. Ich sprzedawcy, podobnie jak dziś muzycy południowoamerykańscy, oferowali utwory napisane i wydrukowane przez kogoś innego, reklamując je własnym śpiewem. Sytuacja ta nie wyklucza jednak faktu istnienia instrumentalistów z Ameryki Południowej, którzy sprzedają swoje autorskie płyty; dobrym przykładem jest wspomniany Noe G. Sanchez.

69 Płyta została zarejestrowana w ukraińskim studiu nagraniowym Audio Centrum w Czortkowie (obwód tarnopolski) w 2014 r. przez Jerzego Majdanyka. Ciekawostką jest to, że w trakcie zakupu przeze mnie omawianego albumu, muzyk wyciągnął z torby puste plastykowe opakowanie, krążek CD (bez nadruku) oraz okładkę, którą przy mnie złożył i umieścił w opakowaniu płyty. 


\section{ZAKOŃCZENIE}

Rozwój fonografii (technik, metod, oprzyrządowania) i wszechobecna kultura masowa nie tylko pozytywnie wpłynęły na udostępnienie szerszemu gronu zainteresowanych możliwości nagrywania i odsłuchiwania muzyki. Wielu z muzyków ulicy korzysta z tej opcji, rejestrując własne albumy płytowe. Prezentują one zróżnicowany poziom wykonania zarejestrowanych kompozycji, jak również niejednorodny pod względem technicznym poziom produkcji (od profesjonalnie wydrukowanych okładek, po ich całkowity brak, od nagrania w studio nagraniowym po rejestracje w domu).

W wyniku globalnego przepływu i krążenia w obiegu niematerialnych dóbr kultury (w tym muzyki), w części nastąpiła też unifikacja repertuaru muzyków ulicy. Jak zauważa Bożena Muszkalska:

[...] nastąpił rozwój mediów, które bez ograniczeń geograficznych udostępniają muzykę światu. Rozprzestrzenienie się kaset, płyt kompaktowych i Internetu wśród muzyków wywołało masową produkcję muzyczną. Elektroniczne sposoby odtwarzania oraz ponadkulturowa produkcja muzyki spowodowały, że organizmy narodowo-państwowe utraciły zdolność tworzenia koherentnych systemów muzycznych. Granice państw przestały pełnić dawną rolę w wyznaczaniu zasięgów kultur muzycznych ${ }^{70}$.

Wiązać z tym można dużą popularność tych samych utworów wśród muzyków ulicy pochodzących z różnych krajów. $\mathrm{Na}$ ich płytach pojawiają się te same kompozycje, jak np. utwór Bésame mucho zarejestrowany przez Noe G. Sancheza, Tadeusza Lisa i Sergiusza Borshcha. Za egzemplifikację dopełniającej globalizację indygenizacji możemy uznać kontrafakturę Wiesława Kuszewskiego - pieśń Samolot zaraz wracać miat. Jest to jednocześnie utwór będący częścią kultury popularnej, a z drugiej strony - pieśń silnie nawiązująca do lokalności poprzez opis zdarzeń ważnych dla konkretnego narodu. W kontekście indygenizacji interesujący jest także fonetyczny zapis tytułów utworów i nazwisk kompozytorów, często spotykany w wydawnictwach muzyków ulicy.

Rozwój fonografii, zmiany technologiczne i cywilizacyjne jako efekt dziewiętnastowiecznych przemian i wynalazków, a także związany z rozwojem cywilizacyjnym proces globalizacyjny, są pewnego rodzaju continuum kierunku zapoczątkowanego w poprzednich stuleciach. W zamyśle Thomasa Alvy Edisona wynalezione przez niego urządzenie do zapisywania dźwięku miało przysłużyć się ludziom uczącym się języków obcych, bądź posłużyć jako biurowy notatnik audio czy dać możliwość przesyłania „dźwiękowych listów” - funkcje te są dziś realizowane dzięki możliwości zapisu i odtwarzania dźwięku, lecz efekty, jakie spowodowało wynalezienie fonografu,

70 Bożena Muszkalska, „Muzykologia wobec globalizacji”, w: Historia, kultura, globalizacja, red. Adam Nobis, Piotr Badyna, Wrocław 2008, s. 54. 
są znacznie większe. Dla muzyków ulicy fonografia, wsparta współczesnymi platformami przekazu i wymiany informacji, oznacza z jednej strony możliwość zapoznawania się z tym, co w danym momencie jest popularne na świecie, co pośrednio wpływa na normalizację repertuaru (te same utwory zyskały popularność w różnych krajach), równocześnie daje również praktycznie nieograniczoną możliwość promowania swojej własnej muzyki (często dochody płynące ze sprzedaży płyt stanowią większą część wszystkich zarabianych w trakcie występu w przestrzeni publicznej pieniędzy). Promocja ta niejednokrotnie ma miejsce także niezależnie od wykonawcy, bowiem muzycy prezentujący się w przestrzeni publicznej dość często są nagrywani przez przechodniów, którzy następnie umieszczają swoje nagrania w Internecie. Przyrost tych źródeł jest znaczny, jednak są one trudne do wykorzystania, albowiem najczęściej nie są opatrzone potrzebnymi metadanymi dotyczącymi muzyka, miejsca i daty nagrania. $Z$ tego powodu istnieje konieczność prowadzenia badań terenowych w konkretnych miejscach i badania lokalnych przejawów muzyki ulicy. To bowiem, że współcześnie żyjemy w Macluhanowskiej globalnej wiosce, nie oznacza równocześnie, że każdy muzyk jest odbiorcą i wyrazicielem „zuniformizowanej kultury globalnej"7I. Rozwój nowych technologii (fonografia, Internet), jak i postępujące procesy globalizacyjne wpływają w istotny sposób na działalność muzyków ulicy, ale jednocześnie nieustannie wyzwalają procesy odśrodkowe (glokalizacja), tym samym sprawiając, że muzyka ulicy to niezwykle barwne, ale i złożone zjawisko kulturowe.

\section{BIBLIOGRAFIA}

Appadurai, Arjun. Nowoczesność bez granic. Kulturowe wymiary globalizacji. Przekł. Zbigniew Pucek. Kraków: Universitas, 2005.

Bass, Michael Thomas. Street Music in the Metropolis. Correspondence and Observations on the Existing Law, and Proposed Amendments. London: John Muray Albemarle Street, I864.

Björk, Rebecka. Bakom kulisserna i Stockholms gatmusikliv. Dysertacja doktorska, Stockholms universitet, 2003.

Boniecki, Adam. „25. Podróż Jana Pawła II. Papież w Peru”. Tygodnik Powszechny 4I, nr 9 (1985): 2-3.

Brzezińska, Barbara. „Zawołania gdańskich domokrążców (I762-1765)”. Muzyka 50, nr 2 (2005): 45-77.

Burke, Peter. Kultura ludowa we wczesnonowożytnej Europie, przekł. Robert Pucek, Michał Szczubiałka. Warszawa: Wydawnictwa Uniwersytetu Warszawskiego, 2009.

Burszta, Wojciech Józef. „Kultury Ludowej już nie będzie, wywiad”. Wywiad Łukasza Grzymisławskiego. Gazeta Wyborcza, 8-9 III 2008. 
Czech, Adam. Sprzedawcy Wiatru. Warszawa: Wydawnictwo Naukowe Scholar, 2008.

Dobrzańska, Joanna. „Muzyk uliczny w przestrzeni Montpellier, Sète i Paryża”. Praca magisterska, Uniwersytet Warszawski 2016.

Dorosz, Piotr. Na Stasiowa nutę. Rzecz o Minskiej Kapeli Matego Stasia i muzyce tradycyjnej wschodniego Mazowsza. Mińsk Mazowiecki: Towarzystwo Przyjaciół Mińska Mazowieckiego, 2018.

Faun. „NNa podwyrzu»... Monografia łódzkiego podwórka. (Szkic z natury)”. Łódzkie Echo Wieczorne, $9 \mathrm{X} 1925$.

Gancarczyk, Paweł. Muzyka wobec rewolucji druku. Przemiany w kulturze muzycznej XVI wieku, Toruń: Wydawnictwo Naukowe UMK, 201 I.

Gomulicki, Wiktor. Przy stońcu i przy gazie: szkice z miasta. Warszawa: S. Lewental, I888.

Grajek Sierota vel Sandomir Icchak. „Grajek sierota”. Maty Przeglad: pismo dzieci i mtodzieży: tygodniowy dodatek bezptatny do nr 72 "Naszego Przegladu”, IO II 1928.

Grochowski, Piotr. Dziady. Rzecz o wędrownych żebrakach i ich pieśniach. Toruń: Wydawnictwo Naukowe UMK, 2009.

Grochowski, Piotr. Straszna zbrodnia rodzonej matki. Polskie pieśni nowiniarskie na przetomie XIX i XX wieku. Toruń: Wydawnictwo Naukowe UMK, 2010.

Grozdew-Kołacińska, Weronika. Śpiewnik dawnej Warszawy. Warszawa: Muzeum Powstania Warszawskiego, 2012.

Grygier, Ewelina, „Street Music. A Case Study of Three European Cities: Vienna, Warsaw and Wrocław". W: Post-ip’i3 - Revista do Fórum Internacional de Estudos em Música e Dança, Aveiro 2013 (v. 2), red. Ana Flávia Miguel, Aoife Hiney, Clarissa Foletto, Gilvano Dalagna, Marcos Vinicius Araújo, Rui Oliveira, 70-77. Aveiro: Departamento de Comunicação e Arte da Universidade de Aveiro, 2013.

Grygier, Ewelina. „O czym śpiewa ulica?”. W: Tubylcy wtasnego świata. W stronę antropologii bliskości, red. Waldemar Kuligowski, I37-I48. Wrocław: Polskie Towarzystwo Ludoznawcze, 2011.

Grygier, Ewelina. „The Repertoire of Street Musicians in a Time of Globalisation”. W: Music Glocalization: Heritage and Innovation in a Digital Age, red. David Herbert, Mikołaj Rykowski, 27I-305. Cambridge: Cambridge Scholars Publishing, 2018.

Grygier, Ewelina. „Uliczny pianista łamiący stereotypy”. Gadki z Chatki. Pismo Folkowe 4, nr II4 (2OI4): 26-27.

Halpern, Feliks. Muzycy w anegdocie i humor muzyczny. Łódź: Księgarnia Karola Neumillera, I929.

Jackowski, Aleksander. „Pojęcie twórcy ludowego”. Lud 64 (I980): 5-23.

Jackowski, Jacek. Zachować dawne nagrania. Zarys historii dokumentacji fonograficznej filmowej polskich tradycji muzycznych i tanecznych, cz. I (przetom XIX i XX w. - do drugiej wojny światowej). Warszawa: Instytut Sztuki PAN, 2014.

James, Barbara. „«Freiheit und Glück!» Strassenmusik heute. Ein Sänger und sein Repertoire”. Jahrbuch für Volksliedforschung 26 (I98I): 75-99.

Janczewska-Sołomko, Katarzyna. Zachować dźwięk. Katalog wystawy w Bibliotece Narodowej. Warszawa: Biblioteka Narodowa, 2000.

Kałtenbergh, Leon. „Muzyka na Starym Mieście”. Stolica I5, nr 39 (I960): I2-I3. 
Kominek, Mieczysław. Zaczęto się od fonografu. Kraków: PWM, I986.

Kopczyńska-Jaworska, Bronisława, Jadwiga Kucharska, Jan Piotr Dekowski. Folklor robotniczej Łodzi. Pokłosie konkursu. Wrocław: Polskie Towarzystwo Ludoznawcze, 1976.

Kurzowa, Zofia, Jerzy Habela. Lwowskie piosenki uliczne, kabaretowe i okolicznościowe do 1939 roku. Kraków: PWM 1989.

Lewandowska, Bożena. „Miasto w tradycji muzycznej folkloru miejskiego: kapele podwórkowe i ich piosenki”. Journal of Urban Ethnology Io (2010): I7-3I.

Losiak, Robert. „Muzyka w przestrzeni publicznej miasta. Z badań nad pejzażem dźwiękowym Wrocławia”. W: Dźwięk w krajobrazie jako przedmiot badań interdyscyplinarnych. Prace Komisji Krajobrazu Kulturowego, red. Sebastian Bernat, 253-264. Lublin: Instytut Nauk o Ziemi, Uniwersytet Marii Curie-Skłodowskiej, 2008.

Michajłowa, Katia. Dziad wędrowny w kulturze ludowej Stowian. Przekł. Hanna Karpińska. Warszawa: Oficyna Naukowa, 2010.

Muszkalska, Bożena. „Muzykologia wobec globalizacji”. W: Historia, kultura, globalizacja, red. Adam Nobis, Piotr Badyna, 54-6o. Wrocław: Wydawnictwo Gajt, 2008.

Pasamonik, Barbara. „Globalizacja kultury czy glokalizacja kultur?”. W: Krótkie wyktady z socjologii: kategorie, problemy, subdyscypliny, red. Anna Firkowska-Mankiewicz, Tatiana Kanasz, Elżbieta Tarkowska, II7-I38. Warszawa: Akademia Pedagogiki Specjalnej im. Marii Grzegorzewskiej, 2013.

„Petronelo, ja cię kocham”. Express Wieczorny Ilustrowany, I6 IX 1927.

Rokosz, Tomasz. Od folkloru do folku. Metamorfozy pieśni tradycyjnych we wspótczesnej kulturze. Siedlce: Wydawnictwo Akademii Podlaskiej, 2009.

Scholes, Percy. „Street Music”. W: The Oxford Companion to Music, red. John Owen Ward, 986-990. London-New York-Toronto: Oxford University Press, I970.

Szacki, Jerzy. Tradycja. Przeglad problematyki. Warszawa: PWN, I97I.

Tyllner, Lubomír. Musikalische Volkskultur in der Stadt der Gegenwart am Beispiel der Strassenmusikanten Stanislav Gana und Erika Babincová in Prag. Ceské lidové pisne a balady, transkrypcja wywiadu z dn. 3 VI 1998, Universität Passau 1998 (materiał niepublikowany).

Wasylkowski, Janusz. Lwowskie Misztygatki. Warszawa: Instytut Lwowski, 2000.

Wasylkowski, Janusz. Piosenki Lwowskiej Ulicy. Antologia. Wrocław: Ośrodek Teatru Otwartego Kalambur, 1987.

Watt, Paul. „Buskers and Busking in Australia in the Nineteenth Century”. Musicology Australia 4I, nr I (2019): 22-35.

Weber, Ernst. „Strassen Musik”. W: Österreichisches Musiklexikon, red. Annemarie Bösch-Niederer, 23-26. Wien: Verlag der Österreichischen Akademie der Wissenschaften, 2006.

Wieczorkiewicz, Bronisław. Warszawskie ballady podwórzowe. Pieśni i piosenki warszawskiej ulicy, opr. Zygmunt Wiehler. Warszawa: PIW, I97I.

„Ze świata Tonów”. Dziennik Łódzki: pismo przemystowe, handlowe i literackie, 29 X I89I. 


\section{THE INFLUENCE OF THE DEVELOPMENT OF THE RECORD INDUSTRY AND GLOBALISATION ON THE REPERTOIRES AND DISC RECORDINGS OF STREET MUSICIANS}

I discuss the repertoires and disc recordings of street musicians within the context of the growth of the record industry and the processes of globalisation and glocalisation. This article is based on field research conducted during work on my $\mathrm{PhD}$ dissertation on contemporary street performance in Poland in light of performance theory. Apart from quotations from the literature, I draw on empirical material collected during that research, including excerpts from interviews with street musicians, to forge a more in-depth picture of the presented phenomenon. In order to trace a broader context, I also present historical data, in particular quotations from the twentieth-century press which refer to the repertoire of musicians performing in the public space. For the needs of my analysis, I first define the scope of the notion of street music, and then discuss and characterise anonymous and authored works, as well as covers of music by other composers. I have paid special attention to the use of contrafacta (including the song Pescador de Hombres, known in Poland as Barka [The boat]) and the possibility of introducing changes to lyrics by other authors. I discuss the pieces of music performed by buskers in Poland, including foreigners who play and sing on our streets, frequently presenting the music of their own countries, as well as well-known works, using what instruments they have to hand (for instance, Latin Americans playing Polish rock hits on the Pan-pipes). I give a detailed profile of discs released by street musicians, which are frequently amateur productions and so fall considerably below professional standards.

Translated by Tomasz Zymer

Słowa kluczowe / keywords: muzyka ulicy / street music, przestrzeń publiczna / public space, muzyka miasta / urban music, muzyka w mieście / music in the city, wydawnictwa płytowe muzyków ulicy / discs released by street musicians

Ewelina Grygier, muzyk i etnomuzykolog. Absolwentka Muzykologii oraz Etnologii i Antropologii Kulturowej UAM, a także Studium Doktoranckiego IS PAN. Obecnie pod kierunkiem prof. Ewy Dahlig-Turek przygotowuje rozprawę doktorską Artysta, performer, żebrak. Zjawisko muzykowania ulicznego $w$ Polsce $w X X I$ wieku $w$ świetle teorii performansu. Jest członkinią międzynarodowej grupy badawczej Street Music Research Group, działającej na uniwersytecie Monash w Australii oraz Polskiego Seminarium Etnomuzykologicznego, w którym pełni funkcję sekretarza. ewelina.grygier@ispan.pl 